\title{
Educação em saúde e diálogos interprofisisonais: considerações sobre uma prática
}

\author{
Leonardo Sales Lima, Geanne Moraes Pires, Denise Herdy Afonso
}

\section{Resumo}

Introdução: Percebendo que as aplicações fragmentadas de técnicas específicas de cada profissional não têm atendido às demandas trazidas pelos usuários,tem-se mobilizado em busca de formular e desenvolver práticas integrativas dos profissionais, afim de atender às demandas apresentadas pelos usuários do SUS. Para isso há a necessidade de ampliação do ensino para além da formação específica, preconizando uma formação multiprofissional e interprofissional. As DCN[7]s (Diretrizes Curriculares Nacionais) dos cursos de Medicina, Fisioterapia e Psicologia, nos artigos $5^{\circ}$ parágrafo IX, $5^{\circ}$ parágrafo III, $8^{\circ}$ parágrafo IX respectivamente, preconizam que a formação deve preparar estes profissionais para uma atuação multiprofissional e interprofissional na atenção à saúde. Mas pode-se notar que ainda há resistência em aderir ao modelo proposto, mantendo-se a prevalência de relações tradicionais nos serviços assistenciais, o que provavelmente pode advir de uma formação tecnicista dos profissionais que integram uma equipe. A educação interprofissional vem como proposta de realização às essas mudanças na formação atual, que produz práticas profissionais específicas para uma perspectiva em que a profissões aprendam de forma integrada o trabalho conjunto e sobre as especificidades de cada uma na melhoria da atenção à saúde dos usuários, [8] conceituada como uma proposta onde 2 ou mais profissões aprendem juntas sobre o trabalho conjunto e sobre as especificidades de cada uma, na melhoria da qualidade no cuidado ao paciente[9]. Objetivos: A pesquisa em questão teve como objetivo primário analisar as experiências em Educação Interprofissional dos estudantes que cursaram a disciplina de Educação em Saúde nos anos de 2015-2016, nos cursos de psicologia, medicina e fisioterapia. Os objetivos secundários foram os de Identificar as competências desenvolvidas durante a educação interprofissional, descrever os sentidos e significados produzidos durante a prática interprofissional e avaliar a implantação da educação interprofisisonal nos cursos de saúde de uma instituição de ensino superior pública Estadual. Método: Tratou-se de uma pesquisa de cunho qualitativo descritiva fenomenológica. A coleta de dados consistiu em entrevista semiestruturada realizada com 30 estudantes que cursaram a disciplina de Educação em Saúde no período de 2015-2016, dos cursos: Fisioterapia, Medicina e Psicologia. O estudo consistiu da análise temática de conteúdo das entrevistas dos discentes que participaram da disciplina "Educação em Saúde". A análise se constituiu em três etapas: exploração do material ou codificação, pré - análise e tratamento do resultado obtido/interpretação. Resultados: Quando indagados sobre o desenvolvimento de competências para o trabalho em equipe e em como a graduação está preparando os futuros profissionais para trabalhar em equipe, os participantes afirmam que estas competências são desenvolvidas nas suas vivências durante a graduação e em outros contextos, não é algo desenvolvido teoricamente, exige que seja realmente em práticas que os façam trabalhar em equipe. E quanto a se as graduações os preparam para trabalhar em equipe os participantes ressaltam que ainda é um processo falho, a graduação tem deixado a desejar quando se trata de preparar para uma prática interprofissional. [8] Praticando, principalmente aqui na formação, que é onde podemos estar todos os dias conversando com estudantes de outros cursos, e trocar informações. É nessa prática na universidade que primeiramente vamos aprender, para quando sair daqui conseguir interagir com outros profissionais. [9] (Participante 12). Indagados acerca do que pensam hoje sobre aprender em conjunto com outros estudantes da área da saúde, e como percebem que a educação interprofissional pode contribuir para uma prática colaborativa, ou seja seus sentidos e significados sobre a educação interprofissional desenvolvidos durante a disciplina, os participantes colocam que 
ISSN 2179-6750

é essencial para as suas futuras atuações profissionais e que assim desenvolveram um olhar ampliado sobre o usuário de saúde e os processos de saúde-doença. Mas também pontuam que ainda falta uma maior organização da oferta desse tipo de metodologia, que os deixou confusos sobre as finalidades, mas ao final eles relatam que o resultado foi compensador. "Acho que a importância é porque o indivíduo ele tem que ser visto como um todo, então como médica eu não posso achar que só eu sou suficiente para dar atenção integral ao paciente, ele precisa também de receber cuidados de saúde mental, tem várias outras coisas que ele precisa, então se a equipe não trabalha junta, ela não consegue garantir o atendimento que ele precisa [9]. (Participante 7) Pudemos constatar que os participantes colocam que a educação Interprofissional oferta uma comunicação efetiva com estudantes de outras áreas, e que assim puderam visualizar como seria um prática colaborativa, muitas vezes vista por eles, como uma prática distante, o que pode se dar pelo fato de ainda predominar um modelo biomédico, com destaque para a especificidade de cada profissão, todos atuando de forma individual, para alcançar objetivos pontuais. Conclusões: Nos relatos dos participantes notou-se que a formação profissional na área da saúde ainda se encontra pautada no desenvolvimento de competências especificas de cada profissão, com locus bem delimitados, com o predomínio do modelo uniprofissional, o que colabora para uma prática individual, rígida e fragmentada, ou seja, o cuidado despendido ao usuário de saúde ocorre de maneira não planejada, negligenciando demandas. Tal fato fortalece os modelos que ainda predominam na formação de profissionais e uma prática biomédica hegemônica. A disciplina de Educação em Saúde é posta como uma possibilidade de prática para desenvolver as competências necessárias para trabalhar em equipe, o que se confirmou no relato dos participantes deste estudo, que trouxeram a necessidade da ampliação dessa experiência para os demais cursos e maior frequência durante a graduação. Os participantes deste estudo apontam que a Educação Interprofissional proporcionou o desenvolvimento de competências para o trabalho em equipe, uma prática efetivamente colaborativa, desenvolver uma melhor comunicação com profissionais de outras áreas e o desenvolvimento de um olhar ampliado sobre as demandas trazidas pelos usuários de saúde.

Descritores: Educação em saúde, Educação Interprofissional em saúde, Ensino na saúde, Formação em saúde. 